\title{
Bioinspired cobalt cubanes with tunable redox potentials for photocatalytic water oxidation and $\mathrm{CO}_{2}$ reduction
}

\author{
Zhishan Luo, Yidong Hou, Jinshui Zhang, Sibo Wang and Xinchen Wang ${ }^{*}$
}

\author{
Full Research Paper \\ Address: \\ State Key Laboratory of Photocatalysis on Energy and Environment, \\ College of Chemistry, Fuzhou University, Fuzhou 350002, China \\ Email: \\ Xinchen Wang* - xcwang@fzu.edu.cn \\ * Corresponding author \\ Keywords: \\ $\mathrm{CO}_{2}$ reduction; cobalt cubane; photocatalysis; water oxidation; water \\ splitting
}

\author{
Beilstein J. Org. Chem. 2018, 14, 2331-2339. \\ doi:10.3762/bjoc. 14.208 \\ Received: 14 May 2018 \\ Accepted: 17 August 2018 \\ Published: 05 September 2018
}

This article is part of the thematic issue "Photoredox catalysis for novel organic reactions".

Guest Editor: P. H. Seeberger

(C) 2018 Luo et al.; licensee Beilstein-Institut.

License and terms: see end of document.

\begin{abstract}
The development of efficient, robust and earth-abundant catalysts for photocatalytic conversions has been the Achilles' heel of solar energy utilization. Here, we report on a chemical approach based on ligand designed architectures to fabricate unique structural molecular catalysts coupled with appropriate light harvesters (e.g., carbon nitride and $\mathrm{Ru}(\mathrm{bpy})_{3}{ }^{2+}$ ) for photoredox reactions. The " $\mathrm{Co}_{4} \mathrm{O}_{4}$ " cubane complex $\mathrm{Co}_{4} \mathrm{O}_{4}\left(\mathrm{CO}_{2} \mathrm{Me}\right)_{4}\left(\mathrm{RNC}_{5} \mathrm{H}_{4}\right)_{4}(\mathrm{R}=\mathrm{CN}, \mathrm{Br}, \mathrm{H}, \mathrm{Me}, \mathrm{OMe})$, serves as a molecular catalyst for the efficient and stable photocatalytic water oxidation and $\mathrm{CO}_{2}$ reduction. A comprehensive structure-function analysis emerged herein, highlights the regulation of electronic characteristics for a molecular catalyst by selective ligand modification. This work demonstrates a modulation method for fabricating effective, stable and earth-abundant molecular catalysts, which might facilitate further innovation in the function-led design and synthesis of cubane clusters for photoredox reactions.
\end{abstract}

\section{Introduction}

The direct conversion of solar energy into chemical fuels (e.g., $\mathrm{H}_{2}$, $\mathrm{CO}$ and hydrocarbons) through water splitting and carbon fixation reactions is a sustainable solution to environmental concerns and long-term access to adequate energy supplies [1-7]. To realize these reactions, extensive studies have focused on the design and synthesis of chemically stable lightharvesting antenna materials and efficient cocatalysts, and their assembly in integrated artificial photosynthetic systems [8-13]. However, such target reactions are typical thermodynamically uphill reactions with large overpotentials, leading to low conversion efficiency. Therefore, the search for suitable cocatalysts to reduce the multielectron involved kinetic barriers for water oxidation and $\mathrm{CO}_{2}$ reduction is regarded as a critical step toward artificial photosynthesis, which can boost the photoconversion efficiency (PCE) significantly [14-19]. 
Molecular catalysts with complex and varied structural motifs are a class of promising catalysts for solar energy conversion, because of their well-controlled functions and tunable nature [20,21]. Their topologies and electron structures can be precisely engineered by ligand design, using the full arsenal of organic chemistry $[22,23]$. These unique structures benefit not only tailoring their redox and kinetic properties for catalysis, but also providing valuable structural information to understand the mechanistic insights of catalytic behavior [24-27]. In addition, the molecular catalysts can either be dissolved in liquids affording a homogeneous catalytic system [28,29], or immobilized on solid surfaces for application in heterogeneous catalysis [30-33], owing to their molecular nature with flexible ligand architectures [34,35]. In this regard, extensive attention has been contributed to the design and synthesis of molecular catalysts [36]. Unfortunately, most of the high-activity molecular catalysts are typically based on noble metals (e.g., Ru, Ir) [37-40], which seriously restricts their practical applications. Therefore, the development of effective, stable and sustainable molecular catalysts based on earth-abundant elements is highly desirable [41-43].

Inspired by the molecular $\mathrm{Mn}_{4} \mathrm{CaO}_{5}$ cubane of oxygen-evolving complex in photosystem II, there is an emerging number of molecular cubanes with metallic and heterobimetallic cores that are designed and synthesized for photosynthesis and electrochemistry. Cobalt-based molecular catalysts [44], in particular the ones containing a cubical $\mathrm{Co}_{4} \mathrm{O}_{4}$ core were studied extensively as energy conversion catalysts, because of their cubical topology that is structurally analogous to the biological $\mathrm{Mn}_{4} \mathrm{CaO}_{5}$ cubane $[45,46]$. Driess et al. have reported the smallest possible molecular building block " $\mathrm{Co}_{4} \mathrm{O}_{4}$ " cluster with a singly deprotonated dipyridyldiol ( $\mathrm{LH})$ as a chelating ligand [47]. Generally, $\mathrm{Co}_{4} \mathrm{O}_{4}$-based molecular catalysts can be easily tuned by ligand design, owing to their molecular nature $[48,49]$. For example, Hill et al. demonstrated that using polytungstate ligands to stabilize " $\mathrm{Co}_{4} \mathrm{O}_{4}$ " cubane units can produce a robust homogeneous catalyst for solar water oxidation [50]. After that, Berlinguette et al. reported that replacing the inorganic ligand with an organic ligand, such as the pentadentate Py5 ligand can also well stabilize the " $\mathrm{Co}_{4} \mathrm{O}_{4}$ " unit to catalyze water oxidation [51]. This finding is very important, which means there is ample choice of organic ligand architectures to tailor the electronic properties of the " $\mathrm{Co}_{4} \mathrm{O}_{4}$ " unit for catalysis. In this regard, Nocera et al. selected an organic ligand bearing an electron-withdrawing group (fluorine) to optimize the " $\mathrm{Co}_{4} \mathrm{O}_{4}$ " cubane unit for electrocatalytic water oxidation [52]. As expected, the resultant catalyst exhibited a larger catalytic current and an earlier onset potential with respect to its analogs without a fluorine functional group. Thus, the control of catalytic properties via molecular design by tunable ligand substitution is essential in the development of $\mathrm{Co}_{4} \mathrm{O}_{4}$-based cubane catalysts. However, most of the researches focused on the oxidative properties of the $\mathrm{Co}_{4} \mathrm{O}_{4}$ core [53], and its use for reduction reactions is rarely covered. Theoretically, the redox potential of $\mathrm{Co}_{4} \mathrm{O}_{4}$ cubane clusters should be tuned by virtue of different ligand substitutions, thus it is highly possible to develop a $\mathrm{Co}_{4} \mathrm{O}_{4}$-based catalyst for reduction applications, such as $\mathrm{H}_{2}$ evolution and $\mathrm{CO}_{2}$ fixation.

Herein, we demonstrate that molecular $\mathrm{Co}_{4} \mathrm{O}_{4}$ cubanes (Figure 1) are readily and precisely manipulated to tune their redox functions through regulating their electronic structures by ligand engineering. The use of electron-withdrawing or donating ligands can easily adjust their catalytic properties for water oxidation and $\mathrm{CO}_{2}$ reduction, respectively. For example, organic ligands with strong electron-withdrawing groups $(\mathrm{R}=\mathrm{CN}, \mathrm{Br}$ ) enhance their oxidation capability for water oxi-
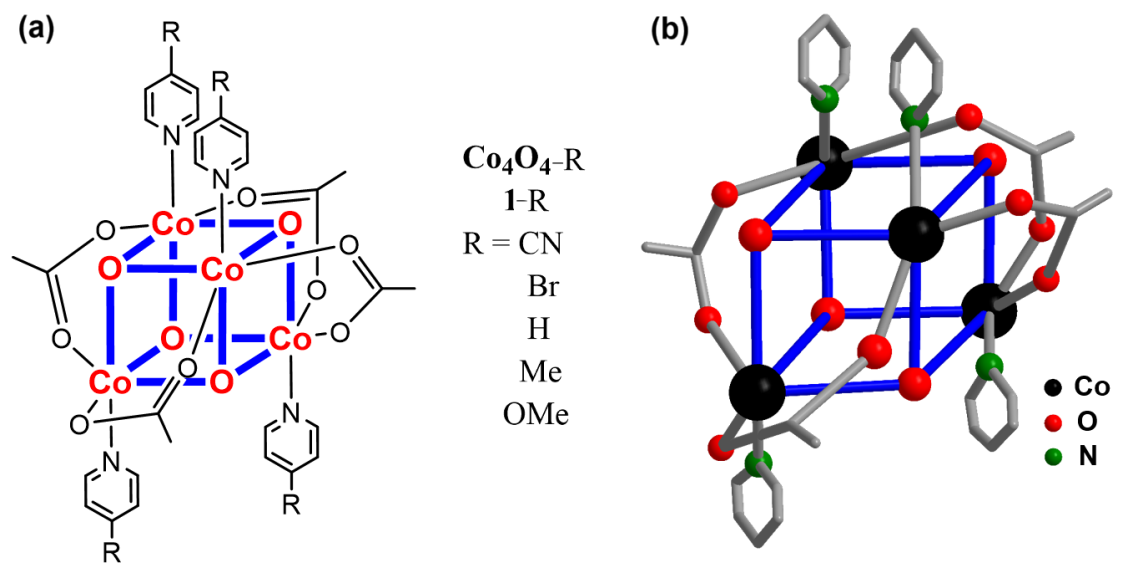

Figure 1: (a) Molecular structures of the $\mathrm{Co}_{4} \mathrm{O}_{4}$ cubane catalysts. (b) Ball-and-stick representation of complex 1- $\mathrm{H}$; $\mathrm{H}$ atoms are omitted for clarity. 
dation by reducing the overpotential of $\mathrm{O}-\mathrm{O}$ bond formation. In contrast, the incorporation of electron-donating groups $(\mathrm{R}=\mathrm{Me}$, $\mathrm{OMe}$ ) significantly increases the electronic density at the metal centers, thus affording a $\mathrm{Co}_{4} \mathrm{O}_{4}$ core able to catalyze $\mathrm{CO}_{2}$ reduction. This indicates that the change of substituents in the pyridine ligand provides further insight into the factors that affect the redox potential and tailor the catalytic performance. Furthermore, by exploring the structure-function relationship at the molecular level offers a useful guidance for the design and construction of high-performance earth-abundant molecular catalysts.

\section{Results and Discussion}

The molecular $\mathrm{Co}_{4} \mathrm{O}_{4}$ cubanes (1-R) were fabricated according to the literature [54], and their identities were confirmed by ${ }^{1} \mathrm{H}$ NMR and FTIR spectroscopy (see Supporting Information File 1 for details). Taking catalyst $\mathbf{1 - H}$ as an example, it's ${ }^{1} \mathrm{H}$ NMR spectrum exhibits three sets of peaks at $8.20(\mathrm{~d}, 8 \mathrm{H})$, $7.71(\mathrm{t}, 4 \mathrm{H})$ and $7.20(\mathrm{t}, 8 \mathrm{H}) \mathrm{ppm}$ for the $o-, p$-, and $m$-ring protons, respectively, of the equivalent pyridines and the methyl protons of the acetate ligands appear as a sharp singlet at 2.06 (s, $12 \mathrm{H}$ ) ppm (see Supporting Information File 1, Figure S1). In the FTIR spectrum, the bands in the region $1530-1538 \mathrm{~cm}^{-1}$ are assigned to the $v_{\text {asym }}(\mathrm{COO})$ vibration and the stretching vibration of the pyridine ring [54], whereas the band at $1410 \mathrm{~cm}^{-1}$ designates to the $\delta_{\text {asym }}\left(\mathrm{CH}_{3}\right)$. The most characteristic feature of the IR data is the appearance of a four-band pattern observed at $\approx 759, \approx 692, \approx 634$ and $\approx 574 \mathrm{~cm}^{-1}$, corresponding to the " $\mathrm{Co}_{4} \mathrm{O}_{4}$ " cubane-like core present in the complex [54]. The XRD patterns for 1-R cubanes are shown in Supporting Information File 1, Figure S8. Moreover, as shown in Scheme S1 (Supporting Information File 1), all aqueous solutions of 1-R are transparent, homogeneous and clear, indicative of their similarities in structure. Based on the above analyses and comparison with the data in literatures [54,55], it is concluded that the 1-R cubanes have been successfully fabricated.

Next, to investigate the effect of different ligands on the optical properties of the 1-R complexes, UV-vis absorption measurements were conducted. As shown in Figure 2, three absorption bands are observed in the UV-vis spectra. The lowest energy absorption appearing as a shoulder at 645 to $660 \mathrm{~nm}$, is associated with the $\mathrm{d}-\mathrm{d}$ transitions involving ${ }^{1} \mathrm{~A}_{1} \rightarrow{ }^{1} \mathrm{~T}_{1}$ and ${ }^{1} \mathrm{~A}_{1} \rightarrow{ }^{1} \mathrm{~T}_{2}$ for the approximately octahedral Co complex [53-55]. As judged by the observed intensities, the other two bands are attributable to absorptions rather than $\mathrm{d}-\mathrm{d}$ transitions. The bands in the range of 340 to $365 \mathrm{~nm}$ are likely due to a charge-transfer transition involving the $\mu$-O-Co moiety present in these complexes $[54,55]$. The observed wavelength shift is dependent on the nature of the substituent present in the $p$-position of the pyridine-based ligand. As expected, the incorporation of the electron-withdrawing moiety $\mathrm{R}=\mathrm{CN}$ reduces the

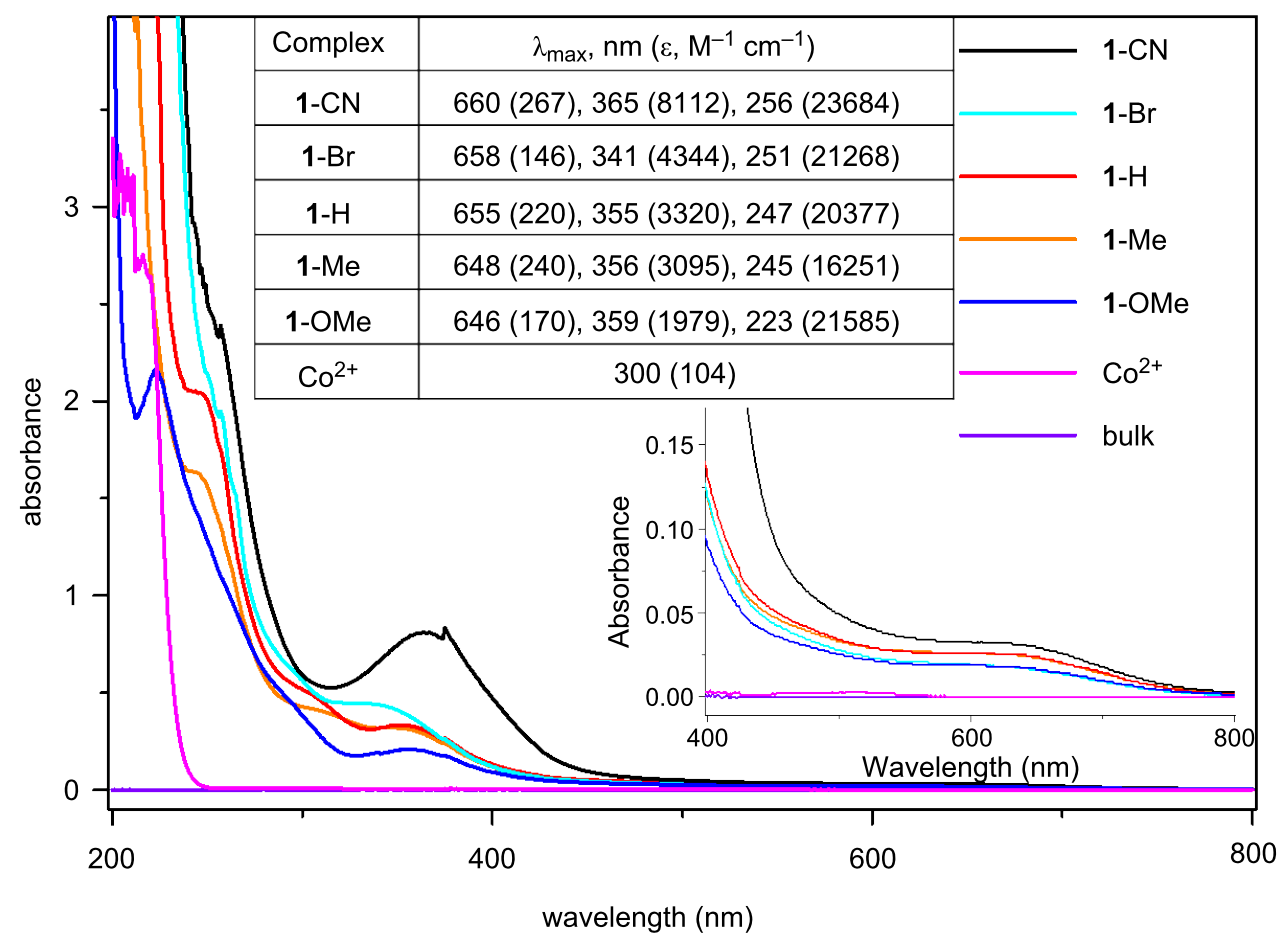

Figure 2: UV-vis absorption spectra of 1-R in $\mathrm{H}_{2} \mathrm{O}$ based on measurements in $10^{-4} \mathrm{M}$ solution. Inset: scale from $400 \mathrm{~nm}$ to $800 \mathrm{~nm}$ and the $\lambda_{\text {max }}$ for 1-R. 
electron densities of the Co centers and thus facilitates the charge-transfer transitions from $\mu-\mathrm{O}$ atoms to the Co centers, which leads to a modest bathochromic shift from $355(\mathrm{R}=\mathrm{H})$ to $365 \mathrm{~nm}$, however, with a remarkably enhanced intensity. In addition, the highest energy band between $220-260 \mathrm{~nm}$ is believed to be of ligand origin, most probably originating from the $\pi \rightarrow \pi^{*}$ absorption of pyridine [54]. Similarly, a red shift in the order of 1-CN $(256 \mathrm{~nm})>1-\mathrm{Br}(251 \mathrm{~nm})>1-\mathrm{H}(247 \mathrm{~nm})>$ 1-Me $(245 \mathrm{~nm})>1$-OMe $(223 \mathrm{~nm})$ is observed based on the increasing electron-withdrawing property of the ligands in these complexes (Figure 2 inset) [55]. This indicates that the different electronic properties have a significant influence on the optical performances, thus underlining the tuning effect of suitably substituted pyridine-based ligands for controlling the catalysts functions.

The subsequent cyclic voltammetry (CV) experiments supported the above results, i.e., that the variation of the ligands has a profound effect on the observed redox potentials. Figure 3 displays the plots of the Hammett $\sigma_{\mathrm{p}}$ parameters for the ligands versus the half-wave potentials $\left(E_{1 / 2}\right)$ for 1-R complexes, and the potentials increase linearly as a function of $\sigma_{\mathrm{p}}$, giving an indicator of the electronic influence of the substituents on $E_{1 / 2}$. The $E_{1 / 2}$ values for the complexes increase in the following order: 1-R, $\mathrm{R}=\mathrm{OMe}<\mathrm{Me}<\mathrm{H}<\mathrm{Br}<\mathrm{CN}$. The Hammett analysis provides a positive slope value, indicating that the $E_{1 / 2}$ value is favored by electron-withdrawing ligands [48,55]. As the ligand becomes more electron withdrawing, the reduced electron density at the metal center makes the Co center in the complex easier to reduce and more difficult to oxidize [55]. Most surprisingly, the potentials could be predicted simply by considering the Hammett $\sigma_{\mathrm{p}}$ values. Therefore, the observed redox potentials reflect a dependence on the electronic properties of the ligand. This again underlines, that the ligands are playing a significant role in the regulation of the redox properties of the 1-R complexes.

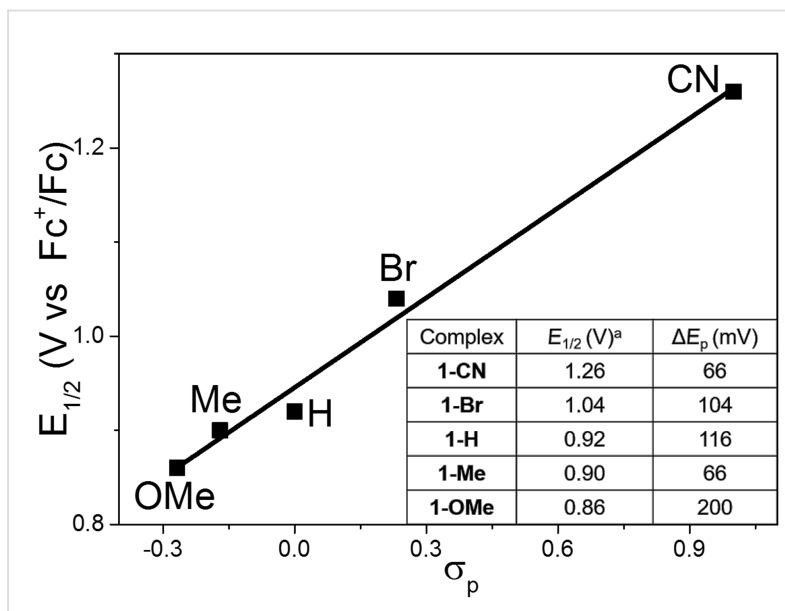

Figure 3: Correlation of Hammett constants $\sigma_{p}$ for the different ligands with midpoint potentials $\left(E_{1 / 2}\right)$ in complexes 1-R. a $C V$ data for 1-R in $\mathrm{MeCN} / 0.1 \mathrm{M}$ TBAP vs $\mathrm{Fc}^{+} / \mathrm{Fc}$ under saturated $\mathrm{Ar}$ atmosphere.

To further estimate the impact of ligand substitution, the complexes were analyzed by linear sweep voltammetry (LSV). For this, we chose complexes 1-CN, 1-H and 1-OMe to include ligand substitutions with electron-withdrawing and electron-donating properties (Figure 4). In Figure 4a, an abrupt onset of the catalytic anode current at $0.7 \mathrm{~V}, 1.0 \mathrm{~V}$ and $1.3 \mathrm{~V}$ for $\mathbf{1 - C N}, \mathbf{1}-\mathrm{H}$ and $1-\mathrm{OMe}$ is observed, respectively, which is ascribed to an $\mathrm{O}_{2}$ evolution reaction. The ligand substituted with the electronwithdrawing cyano $(\mathbf{C N})$ group shows the lowest overpotential
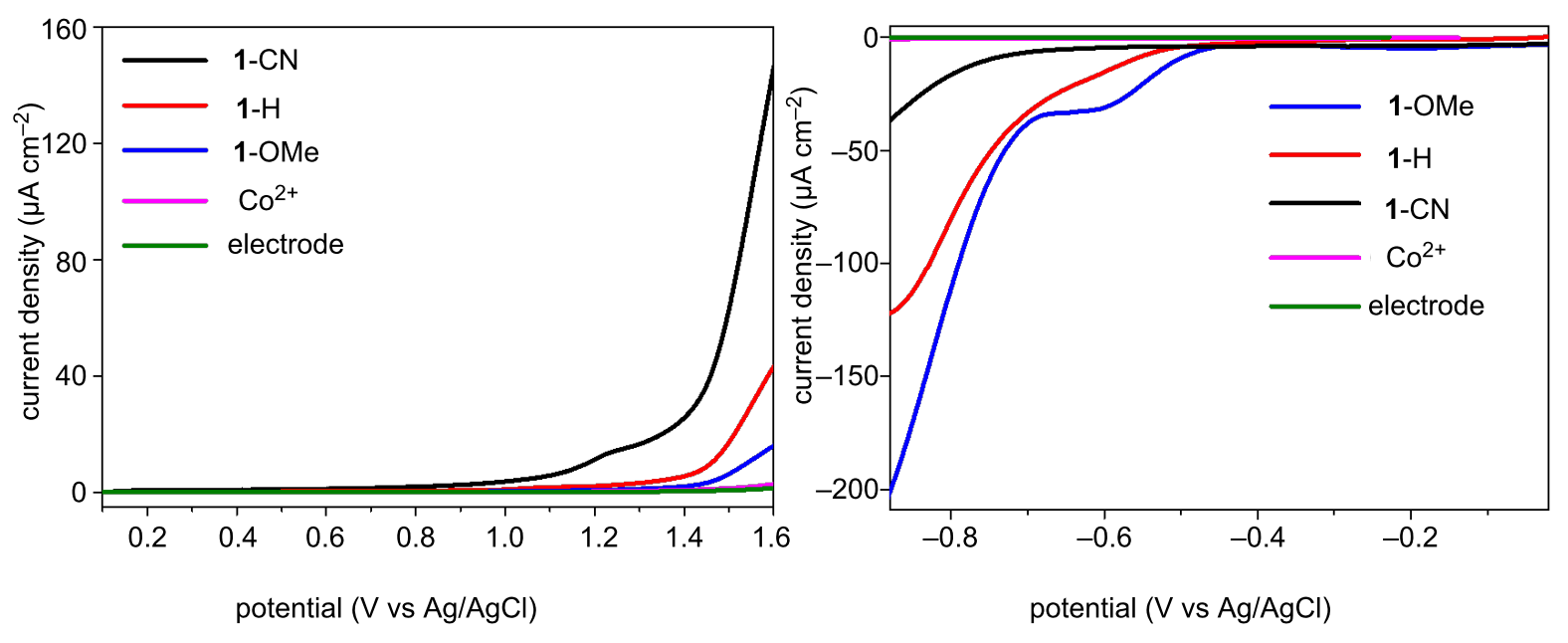

Figure 4: Linear sweep voltammetry of 1-R $(0.3 \mathrm{mM})$ or $\mathrm{Co}\left(\mathrm{NO}_{3}\right)_{2} \cdot 6 \mathrm{H}_{2} \mathrm{O}(1.2 \mathrm{mM}) ;\left(\right.$ a) at a $100 \mathrm{mV} / \mathrm{s}$ scan rate in $0.2 \mathrm{M} \mathrm{Na} \mathrm{SO}_{4},(\mathrm{~b})$ at a $50 \mathrm{mV} / \mathrm{s}$ scan rate in $\mathrm{MeCN}\left(0.1 \mathrm{M} \mathrm{TBAPF}_{6}\right)$ under $\mathrm{CO}_{2}$-saturated conditions. The working electrode used was 3 mm diameter glassy carbon electrode, the counter electrode was a platinum foil and the reference electrode was a $\mathrm{Ag} / \mathrm{AgCl}$. 
for water oxidation activities, exhibiting a much higher current density compared to other cubane complexes and $\mathrm{Co}^{2+}$. Meanwhile, we also studied the electrochemical reduction in $\mathrm{CO}_{2-}$ saturated system (Figure $4 \mathrm{~b}$ ). It displays that 1 -OMe affords a current density of $200 \mu \mathrm{A} \cdot \mathrm{cm}^{-2}$ at $-0.88 \mathrm{~V}$, a 5.5 -fold enhancement over 1-CN $\left(36 \mu \mathrm{A} \cdot \mathrm{cm}^{-2}\right)$. This suggests that the substituted ligand with the electron-donating group is suitable for the electrochemical reduction. It is important to note that ligands with different electronic structures exhibited starkly different activities for redox reaction. The ligand with an electron-withdrawing property favors water oxidation, and the one with electron-donating property is conducive to $\mathrm{CO}_{2}$ reduction. Such a favorable electrochemical potential for 1-R with tunable ligand substitutions suggests their great potential as redox catalysts for water oxidation and $\mathrm{CO}_{2}$ reduction reactions.

Next, we studied the photocatalytic activity of a series of the 1-R molecular complexes in the water oxidation reaction to release $\mathrm{O}_{2}$ gas and $\mathrm{CO}_{2}$-to- $\mathrm{CO}$ conversion (Figure 5). For the water oxidation, we have chosen carbon nitride [56-60] coupled with the 1-R molecular complexes to evaluate the oxygen evolution performance. In Figure 5a, without the 1-R molecular complexes, the $\mathrm{O}_{2}$ production rate is rather low $\left(1.2 \mu \mathrm{mol} \cdot \mathrm{h}^{-1}\right)$. However, after introducing the molecular complexes, the oxygen evolution reaction is accelerated, and the reactivity of the reaction is expected to be tuned by the ligand modification, within the order of $1-\mathrm{CN}\left(10.2 \mu \mathrm{mol} \cdot \mathrm{h}^{-1}\right)>1-\mathrm{Br}\left(5.9 \mu \mathrm{mol} \cdot \mathrm{h}^{-1}\right)$ $>1-\mathrm{H}\left(4.9 \mu \mathrm{mol} \cdot \mathrm{h}^{-1}\right)>1-\mathrm{Me}\left(4.5 \mu \mathrm{mol} \cdot \mathrm{h}^{-1}\right)>1-\mathrm{OMe}$ $\left(3.3 \mu \mathrm{mol} \cdot \mathrm{h}^{-1}\right)$, which is consistent with the effect of the substituent groups on the pyridine ligand of 1-R on the electrochemical oxygen evolution. These results indicated that water oxidation is favored by the presence of electron-withdrawing ligands. Additionally, the activity of water oxidation over 1-R is much higher than that over $\mathrm{Co}^{2+}$ ions, which may be due to the effect of the ligand for enhancing the stability of the entire cobalt metal center $[48,49]$. Furthermore, a long time course of water oxidation for 1-CN and $\mathrm{Co}^{2+}$ are also compared in Figure 6. It is obvious that the overall amount of the produced $\mathrm{O}_{2}$ gas for 1-R is higher than that for $\mathrm{Co}^{2+}$. As the reaction time increases,

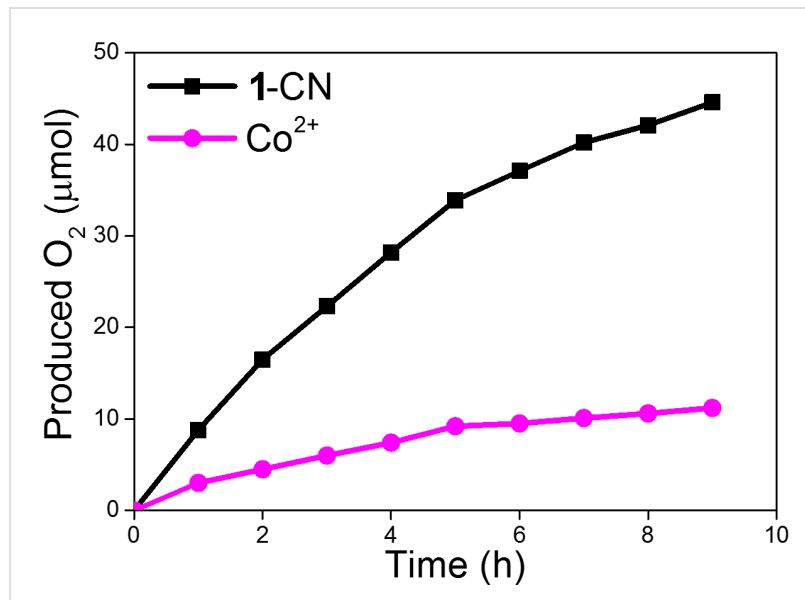

Figure 6: Long-time course of water oxidation for 1-CN and $\mathrm{Co}^{2+}$ under UV-vis light irradiation $(\lambda>300 \mathrm{~nm})$.
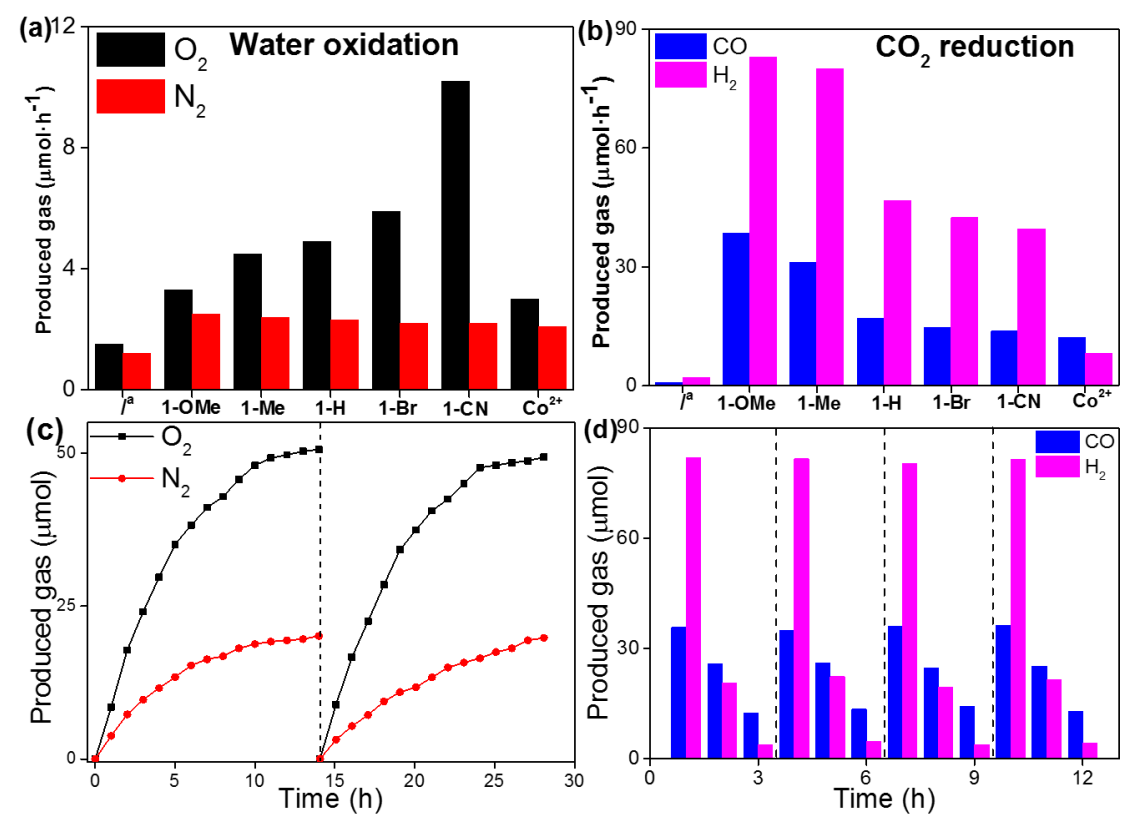

Figure 5: The activity of 1-R for (a) water oxidation and (b) $\mathrm{CO}_{2}$ reduction. (c) Long-time course of water oxidation for 1-CN under UV-vis light irradiation $(\lambda>300 \mathrm{~nm})$ in two recycling tests. (d) $\mathrm{CO}_{2}$ reduction for 1-OMe under visible light irradiation $(\lambda>420 \mathrm{~nm})$ in four recycling tests. ${ }^{a}$ Without $1-\mathrm{R}$. 
the decreasing trend of $\mathrm{O}_{2}$ evolution rate for $\mathrm{Co}^{2+}$ is more pronounced than in case of 1-CN. This can be ascribed to the instability of $\mathrm{Co}^{2+}$ and the tendency of this metal to be oxidized to form $\mathrm{CoO}_{x}$ nanoparticles in the reaction mixture (Supporting Information File 1, Figure S7). These results also support the above discussion. The presence of 1-R with an enhanced electron-withdrawing ability can significantly reduce the overpotential for the $\mathrm{O}-\mathrm{O}$ bond formation, and thus facilitates water oxidation.

Besides the $\mathrm{CO}_{2}$ reduction performance of the molecular complexes was evaluated by cooperation with a ruthenium photosensitizer $\mathrm{Ru}(\mathrm{bpy}) 3^{2+}$ (bpy $=2$ ', 2-bipyridine) with visible light irradiation [61-67]. As shown in Figure 5b, the activity of the $\mathrm{CO}_{2}$ reaction is reduced with the increase of electron-withdrawing ability of the ligand. In this case, 1-OMe exhibits the highest $\mathrm{CO}_{2}$ photoreduction activity with a $\mathrm{CO}$ evolution rate of $38.5 \mu \mathrm{mol} \cdot \mathrm{h}^{-1}$, together with a $\mathrm{H}_{2}$ generation rate of $83 \mu \mathrm{mol} \cdot \mathrm{h}^{-1}$. The $\mathrm{CO}_{2}$-to-CO conversion rate of $1-\mathrm{OMe}$ is 2.5 fold enhanced than that of $1-\mathrm{CN}\left(13.8 \mu \mathrm{mol} \cdot \mathrm{h}^{-1}\right)$. It is found that the introduction of a simple substituent greatly influenced the activity of $\mathrm{CO}_{2}$ reduction, that is, the ligand substitution with an electron-donating property is more beneficial for the $\mathrm{CO}_{2}$ reduction reaction. The above results demonstrate that the 1-R molecular complexes are highly active for both water oxidation and $\mathrm{CO}_{2}$ reduction reactions, which is in good agreement with the results of the optical, CV and LSV measurements. Importantly, the photoredox functions of the molecular complexes can be modulated deliberately by ligand substitutions with different electronic properties.

The stabilities of the molecular catalysts for photoredox reactions were also examined. Firstly, in $14 \mathrm{~h}$ long term water oxidation tests for 2 cycles, the total $\mathrm{O}_{2}$ evolution in each run was almost the same (Figure 5c). The gradually reduced reaction rate after about $5 \mathrm{~h}$ is ascribed to the deposition of $\mathrm{Ag}$ particles on the surface of polymeric carbon nitride $\left(\mathrm{p}-\mathrm{C}_{3} \mathrm{~N}_{4}, \mathrm{PCN}\right)$, which leads to a light shading effect hindering optical absorption. In the stability test for $\mathrm{CO}_{2}$ reduction reactions, no noticeable losses in the yields of $\mathrm{CO}$ and $\mathrm{H}_{2}$ were observed in 4 cycles (Figure $5 \mathrm{~d}$ ). The deactivation after $3 \mathrm{~h}$ reaction in each case is due to photobleaching of the used dye photosensitizer. Moreover, after water oxidation and $\mathrm{CO}_{2}$ reduction reactions, the structures of 1-CN and 1-OMe were studied by ${ }^{1} \mathrm{H}$ NMR spectroscopy, and no obvious changes were observed compared with the fresh samples (Supporting Information File 1, Figure S6).

\section{Conclusion}

In summary, we have developed molecular cubane catalysts with tunable redox potentials through the ligand architectures, which are coupled with the light harvesters (e.g., carbon nitride and $\mathrm{Ru}(\mathrm{bpy})_{3}{ }^{2+}$ ) for photocatalytic water oxidation and $\mathrm{CO}_{2}$ reduction. The electronic properties of the ligands have a significant effect on the catalysts photoredox reaction. The ligands with electron-withdrawing substituents are beneficial for the water oxidation and the $\mathrm{CO}_{2}$ reduction is favored by the presence of electron-donating ligands. The comparative study reported here allows us to scrutinize the interplay between electronic effects and redox potential caused by ligand modifications within the series of $\mathrm{Co}_{4} \mathrm{O}_{4}$ cubane clusters. The ligand modification strategy developed here provides a rational, precise and cost-effective way for the chemical design and synthesis of biomimetic cubane clusters with metal cores (i.e., $\mathrm{Co}, \mathrm{Mn}$, and $\mathrm{Ni}$ ) or even heterobimetallic cores for a wide range of redox applications in catalysis and photosynthesis.

\section{Experimental}

Materials: All chemicals are commercially available and were used without further purification. All solutions were prepared with Milli-Q ultrapure water ( $>18 \mathrm{M} \Omega$ ) unless otherwise stated.

Synthesis of $\mathbf{p}-\mathbf{C}_{\mathbf{3}} \mathbf{N}_{\mathbf{4}}: \mathbf{p}-\mathrm{C}_{3} \mathrm{~N}_{4}$ was synthesized by annealing urea $(10 \mathrm{~g})$ at $550{ }^{\circ} \mathrm{C}$ for $2 \mathrm{~h}$ under the muffle furnace with the ramping rate at $5{ }^{\circ} \mathrm{C} / \mathrm{min}$, and the resulted buff powder was collected and denoted as PCN.

Synthesis of ATCN/p- $\mathbf{C}_{3} \mathbf{N}_{4}$ : The ATCN/p- $\mathrm{C}_{3} \mathrm{~N}_{4}$ sample was synthesized according to the literature procedures [68]. 2-Aminothiophene-3-carbonitrile (ATCN, $10 \mathrm{mg}$ ) and $10 \mathrm{~g}$ urea were mixed with $10 \mathrm{~mL}$ pure water, and stirring at room temperature for $12 \mathrm{~h}$ and then stirring at $80{ }^{\circ} \mathrm{C}$ to remove water. The mixtures were ground into powder and calcined at $550{ }^{\circ} \mathrm{C}$ for $2 \mathrm{~h}$ under the muffle furnace with the ramping rate at $5{ }^{\circ} \mathrm{C} / \mathrm{min}$. The samples thus obtained were denoted as ATCN/PCN.

Synthesis of $\mathrm{Co}_{4} \mathrm{O}_{4}\left(\mathrm{O}_{2} \mathrm{CMe}\right)_{4}\left(\mathrm{NC}_{5} \mathrm{H}_{5}\right)_{4}, \mathbf{1 - H}$ : Complex 1-H was synthesized according to the literature procedures $[30,48,54]$. Typically, to a mixture of $\mathrm{Co}\left(\mathrm{NO}_{3}\right)_{2} \cdot 6 \mathrm{H}_{2} \mathrm{O}(2.9 \mathrm{~g}$, $10 \mathrm{mmol})$ and $\mathrm{CH}_{3} \mathrm{CO}_{2} \mathrm{Na} \cdot 3 \mathrm{H}_{2} \mathrm{O}(2.7 \mathrm{~g}, 20 \mathrm{mmol})$ in methanol $(30 \mathrm{~mL})$ heated to refluxing temperature, is added pyridine $(0.8 \mathrm{~mL}, 10 \mathrm{mmol})$ while stirring. Then a portion of $30 \%$ hydrogen peroxide (v/v, $5 \mathrm{~mL}, 50 \mathrm{mmol}$ ) is slowly added to the reaction mixture, and stirring under refluxing conditions is continued for $4 \mathrm{~h}$. After cooling to room temperature and reducing the volume, the latter is placed in a separating funnel and $\mathrm{CH}_{2} \mathrm{Cl}_{2}$ added. The pink aqueous phase was discarded, while the dark green organic phase dried over anhydrous $\mathrm{Na}_{2} \mathrm{SO}_{4}$ and filtered. After removal of the solvent, the residue was purified by column chromatography on silica gel with 
$\mathrm{CH}_{2} \mathrm{Cl}_{2} / \mathrm{CH}_{3} \mathrm{OH}$ 15:1 (v/v) as the eluent to afford $1.50 \mathrm{~g}(70 \%)$ of the pure complex as a dark green solid.

Synthesis of $\mathrm{Co}_{4} \mathrm{O}_{4}\left(\mathrm{O}_{2} \mathrm{CMe}\right)_{4}\left(\mathrm{NC}_{5} \mathrm{H}_{4}-\mathrm{OMe}\right)_{4}, 1-\mathrm{OMe}$ : The same procedure as described above was adopted except replacing pyridine with 4-methoxypyridine $(1.02 \mathrm{~mL}$, $10 \mathrm{mmol})$, to afford $2.07 \mathrm{~g}(85 \%)$ of the dark green product.

Synthesis of $\mathrm{Co}_{4} \mathrm{O}_{4}\left(\mathrm{O}_{2} \mathrm{CMe}\right)_{4}\left(\mathrm{NC}_{5} \mathrm{H}_{4}-\mathrm{Me}\right)_{4}$, 1-Me: A similar procedure as described above was adopted using 4-methylpyridine $(0.98 \mathrm{~mL}, 10 \mathrm{mmol})$ to afford $1.82 \mathrm{~g}(80 \%)$ of the dark green product.

Synthesis of $\mathrm{Co}_{4} \mathrm{O}_{4}\left(\mathrm{O}_{2} \mathrm{CMe}\right)_{\mathbf{4}}\left(\mathrm{NC}_{5} \mathrm{H}_{4}-\mathrm{Br}\right)_{4}, \mathbf{1 - B r}$ : The same procedure as described above was adopted except replacing pyridine with 4-bromopyridine hydrochloride (1.94 g, $10 \mathrm{mmol})$ to afford $0.9 \mathrm{~g}(31 \%)$ of the dark green product.

Synthesis of $\mathrm{Co}_{4} \mathrm{O}_{\mathbf{4}}\left(\mathrm{O}_{2} \mathrm{CMe}\right)_{\mathbf{4}}\left(\mathrm{NC}_{\mathbf{5}} \mathrm{H}_{\mathbf{4}}-\mathrm{CN}\right)_{\mathbf{4}}, \mathbf{1 - C N}$ : The same procedure as described above was adopted except replacing pyridine with 4-cyanopyridine $(1.04 \mathrm{~mL}, 10 \mathrm{mmol})$ to afford $2.01 \mathrm{~g}(84 \%)$ of the product as dark brown solid.

Characterization: The UV-vis absorption spectra were measured on a SHIMADZU UV-1780 spectrometer (Kyoto, Japan). Fourier transform infrared (FTIR) spectra were taken on a thermo Nicolet Nexus 670 FTIR spectrometer with $\mathrm{KBr}$ as the diluents. Electrochemical measurements were conducted with a Biologic VSP-300 Electrochemical System in a conventional three electrode cell. The ${ }^{1} \mathrm{H}$ NMR experiments were performed on Bruker AVANCE 400M spectrometers. Transmission electron microscopy (TEM) was obtained using a FEI TECNAIG2F20 instrument. Powder X-ray diffraction (XRD) patterns were collected on Bruker D8 Advance diffractometer with $\mathrm{Cu} \mathrm{K} 1$ radiation $(\lambda=1.5406 \AA)$.

Photocatalytic test for water oxidation system [69]: Photocatalytic $\mathrm{O}_{2}$ production was carried out in a Pyrex top-irradiation reaction vessel connected to a glass closed gas circulation system. For each reaction, PCN powder $(50 \mathrm{mg})$ was well dispersed in an aqueous solution $(100 \mathrm{~mL})$ containing $\mathrm{AgNO}_{3}$ $(0.17 \mathrm{~g})$ as an electron acceptor, $\mathrm{La}_{2} \mathrm{O}_{3}(0.2 \mathrm{~g})$ as a $\mathrm{pH}$ buffer agent and 1-R $(0.25 \mu \mathrm{mol})$ or $\mathrm{Co}\left(\mathrm{NO}_{3}\right)_{2} \cdot 6 \mathrm{H}_{2} \mathrm{O}(1.0 \mu \mathrm{mol})$. The reaction solution was evacuated several times to remove air completely prior to irradiation with a $300 \mathrm{~W}$ xenon lamp with a working current of 15 A (Shenzhen ShengKang Technology Co., Ltd, China, LX300F). The wavelength of the incident light was controlled by applying some appropriate long-pass cut-off filters $(\lambda>300 \mathrm{~nm})$. The temperature of the reaction solution was maintained at room temperature by a flow of cooling water during the reaction. The evolved gases were analyzed in-situ by gas chromatography equipped with a thermal conductive detector (TCD) and a $5 \AA$ molecular sieves column, using Argon as the carrier gas.

Photocatalytic test for $\mathrm{CO}_{2}$ reduction system [70]: The photocatalytic test was performed in a Schlenk flask $(80 \mathrm{~mL})$ under an atmospheric pressure of $\mathrm{CO}_{2}$. In the Schlenk flask, the photocatalytic $\mathrm{CO}_{2}$ reduction reaction was carried out by dispersing $\mathrm{Ru}$ (bpy) ${ }_{3}{ }^{2+}(7.8 \mathrm{mg})$ in $\mathrm{MeCN}(4 \mathrm{~mL})$ containing triethanolamine (TEOA, $1 \mathrm{~mL})$ and $1-\mathrm{R}(0.25 \mu \mathrm{mol})$ or $\mathrm{Co}\left(\mathrm{NO}_{3}\right)_{2} \cdot 6 \mathrm{H}_{2} \mathrm{O}(1.0 \mu \mathrm{mol})$. This mixture was subjected to vacuum degassing and then back filling with pure $\mathrm{CO}_{2}$ gas. This process was repeated three times, and after the last cycle, the flask was back filled with $\mathrm{CO}_{2}$ (1 bar). The temperature of the reaction solution was maintained at $30{ }^{\circ} \mathrm{C}$ controlled by a flow of warm water during the reaction. Then, the system was irradiated with a $300 \mathrm{~W}$ Xenon lamp with a $420 \mathrm{~nm}$ cut-off filter under vigorous stirring. The produced gases $\left(\mathrm{CO}\right.$ and $\left.\mathrm{H}_{2}\right)$ were detected using a gas chromatograph equipped with a packed molecular sieves column (TDX-1 mesh 42/10); Argon was used as the carrier gas.

\section{Supporting Information}

\section{Supporting Information File 1}

Additional data.

[https://www.beilstein-journals.org/bjoc/content/ supplementary/1860-5397-14-208-S1.pdf]

\section{Acknowledgements}

This work was financially supported by the National Key Technologies R \& D Program of China (2018YFA0209301), the National Natural Science Foundation of China (21425309, 21761132002, and 21861130353), and the 111 Project.

\section{ORCID ${ }^{\circledR}$ iDs}

Jinshui Zhang - https://orcid.org/0000-0003-4649-6526

Sibo Wang - https://orcid.org/0000-0003-2656-9169

\section{References}

1. Garrido-Barros, P.; Gimbert-Suriñach, C.; Matheu, R.; Sala, X.; Llobet, A. Chem. Soc. Rev. 2017, 46, 6088-6098. doi:10.1039/C7CS00248C

2. Chu, S.; Majumdar, A. Nature 2012, 488, 294-303. doi:10.1038/nature11475

3. Wang, S.; Guan, B. Y.; Lu, Y.; Lou, X. W. D. J. Am. Chem. Soc. 2017, 139, 17305-17308. doi:10.1021/jacs.7b10733

4. Wang, S.; Wang, X. Angew. Chem., Int. Ed. 2016, 55, 2308-2320. doi:10.1002/anie.201507145

5. Wang, S.; Guan, B. Y.; Lou, X. W. D. Energy Environ. Sci. 2018, 11, 306-310. doi:10.1039/C7EE02934A 
6. Wang, S.; Guan, B. Y.; Lou, X. W. D. J. Am. Chem. Soc. 2018, 140, 5037-5040. doi:10.1021/jacs.8b02200

7. Liu, Y.; Huang, B.; Xie, Z. Appl. Surf. Sci. 2018, 427, 693-701. doi:10.1016/j.apsusc.2017.08.098

8. Zhang, M.; Luo, Z.; Zhou, M.; Zhang, G.; Alamry, K. A.; Taib, L. A.; Asiri, A. M.; Wang, X. Appl. Catal., B: Environ. 2017, 210, 454-461. doi:10.1016/j.apcatb.2017.03.080

9. Kärkäs, M. D.; Verho, O.; Johnston, E. V.; Åkermark, B. Chem. Rev. 2014, 114, 11863-12001. doi:10.1021/cr400572f

10. Guo, F.; Hou, Y.; Asiri, A. M.; Wang, X. Chem. Commun. 2017, 53, 13221-13224. doi:10.1039/C7CC07805F

11. Zhang, G.; Lan, Z.-A.; Wang, X. Chem. Sci. 2017, 8, 5261-5274. doi:10.1039/C7SC01747B

12. Chen, L.; Gu, Q.; Hou, L.; Zhang, C.; Lu, Y.; Wang, X.; Long, J. Catal. Sci. Technol. 2017, 7, 2039-2049. doi:10.1039/C7CY00495H

13. Pang, A.; Sun, X.; Ruan, H.; Li, Y.; Dai, S.; Wei, M. Nano Energy 2014, 5, 82-90. doi:10.1016/j.nanoen.2014.02.007

14. Ran, J.; Zhang, J.; Yu, J.; Jaroniec, M.; Qiao, S. Z. Chem. Soc. Rev. 2014, 43, 7787-7812. doi:10.1039/C3CS60425J

15. Yang, J.; Wang, D.; Han, H.; Li, C. Acc. Chem. Res. 2013, 46, 1900-1909. doi:10.1021/ar300227e

16. Tachibana, Y.; Vayssieres, L.; Durrant, J. R. Nat. Photonics 2012, 6, 511-518. doi:10.1038/nphoton.2012.175

17. Sun, J.; Zhang, J.; Zhang, M.; Antonietti, M.; Fu, X.; Wang, X. Nat. Commun. 2012, 3, No. 1139. doi:10.1038/ncomms2152

18. Yang, P.; Wang, R.; Zhou, M.; Wang, X. Angew. Chem., Int. Ed. 2018, 57, 8674-8677. doi:10.1002/anie.201804996

19. Yang, P.; Ou, H.; Fang, Y.; Wang, X. Angew. Chem., Int. Ed. 2017, 56, 3992-3996. doi:10.1002/anie.201700286

20. Bonin, J.; Maurin, A.; Robert, M. Coord. Chem. Rev. 2017, 334, 184-198. doi:10.1016/j.ccr.2016.09.005

21. Wu, X.; Li, F.; Zhang, B.; Sun, L. J. Photochem. Photobiol., C 2015, 25, 71-89. doi:10.1016/j.jphotochemrev.2015.07.002

22. Nguyen, A. I.; Wang, J.; Levine, D. S.; Ziegler, M. S.; Tilley, T. D. Chem. Sci. 2017, 8, 4274-4284. doi:10.1039/C7SC00627F

23. Das, B.; Ezzedinloo, L.; Bhadbhade, M.; Bucknall, M. P.; Colbran, S. B. Chem. Commun. 2017, 53, 10006-10009. doi:10.1039/C7CC06294J

24. McAlpin, J. G.; Stich, T. A.; Ohlin, C. A.; Surendranath, Y.; Nocera, D. G.; Casey, W. H.; Britt, R. D. J. Am. Chem. Soc. 2011, 133, 15444-15452. doi:10.1021/ja202320q

25. Hodel, F. H.; Luber, S. ACS Catal. 2016, 6, 1505-1517. doi:10.1021/acscatal.5b02507

26. Nguyen, A. I.; Ziegler, M. S.; Oña-Burgos, P.; Sturzbecher-Hohne, M.; Kim, W.; Bellone, D. E.; Tilley, T. D. J. Am. Chem. Soc. 2015, 137, 12865-12872. doi:10.1021/jacs.5b08396

27. Li, X.; Siegbahn, P. E. M. J. Am. Chem. Soc. 2013, 135, 13804-13813. doi:10.1021/ja4053448

28. Song, F.; Moré, R.; Schilling, M.; Smolentsev, G.; Azzaroli, N.; Fox, T.; Luber, S.; Patzke, G. R. J. Am. Chem. Soc. 2017, 139, 14198-14208. doi:10.1021/jacs.7b07361

29. Bi, W.; Li, X.; Zhang, L.; Jin, T.; Zhang, L.; Zhang, Q.; Luo, Y.; Wu, C.; Xie, Y. Nat. Commun. 2015, 6, No. 8647. doi:10.1038/ncomms9647

30. Wang, Y.; Li, F.; Zhou, X.; Yu, F.; Du, J.; Bai, L.; Sun, L. Angew. Chem., Int. Ed. 2017, 56, 6911-6915. doi:10.1002/anie.201703039

31. Wang, Y.; Li, F.; Li, H.; Bai, L.; Sun, L. Chem. Commun. 2016, 52, 3050-3053. doi:10.1039/C5CC09588C

32. Schreier, M.; Luo, J.; Gao, P.; Moehl, T.; Mayer, M. T.; Grätzel, M. J. Am. Chem. Soc. 2016, 138, 1938-1946. doi:10.1021/jacs.5b12157
33. Zhang, B.; Li, F.; Yu, F.; Wang, X.; Zhou, X.; Li, H.; Jiang, Y.; Sun, L. ACS Catal. 2014, 4, 804-809. doi:10.1021/cs401109u

34. Azcarate, I.; Costentin, C.; Robert, M.; Savéant, J.-M. J. Am. Chem. Soc. 2016, 138, 16639-16644. doi:10.1021/jacs.6b07014

35. Smith, P. F.; Kaplan, C.; Sheats, J. E.; Robinson, D. M.; McCool, N. S.; Mezle, N.; Dismukes, G. C. Inorg. Chem. 2014, 53, 2113-2121. doi:10.1021/ic402720p

36. Blakemore, J. D.; Crabtree, R. H.; Brudvig, G. W. Chem. Rev. 2015, 115, 12974-13005. doi:10.1021/acs.chemrev.5b00122

37. Kang, P.; Chen, Z.; Nayak, A.; Zhang, S.; Meyer, T. J. Energy Environ. Sci. 2014, 7, 4007-4012. doi:10.1039/C4EE01904K

38. Duan, L.; Bozoglian, F.; Mandal, S.; Stewart, B.; Privalov, T.; Llobet, A.; Sun, L. Nat. Chem. 2012, 4, 418-423. doi:10.1038/nchem.1301

39. Chen, Z.; Concepcion, J. J.; Brennaman, M. K.; Kang, P.; Norris, M. R.; Hoertz, P. G.; Meyer, T. J. Proc. Natl. Acad. Sci. U. S. A. 2012, 109, 15606-15611. doi:10.1073/pnas.1203122109

40. Huang, H.; Lin, J.; Zhu, G.; Weng, Y.; Wang, X.; Fu, X.; Long, J. Angew. Chem., Int. Ed. 2016, 55, 8314-8318. doi:10.1002/anie.201602796

41. Han, X.-B.; Zhang, Z.-M.; Zhang, T.; Li, Y.-G.; Lin, W.; You, W.; Su, Z.-M.; Wang, E.-B. J. Am. Chem. Soc. 2014, 136, 5359-5366. doi:10.1021/ja412886e

42. Zhang, G.; Zhang, M.; Ye, X.; Qiu, X.; Lin, S.; Wang, X. Adv. Mater. 2014, 26, 805-809. doi:10.1002/adma.201303611

43. Zhang, J.; Zhang, G.; Chen, X.; Lin, S.; Möhlmann, L.; Dołęga, G.; Lipner, G.; Antonietti, M.; Blechert, S.; Wang, X. Angew. Chem., Int. Ed. 2012, 51, 3183-3187. doi:10.1002/anie.201106656

44. Artero, V.; Chavarot-Kerlidou, M.; Fontecave, M. Angew. Chem., Int. Ed. 2011, 50, 7238-7266. doi:10.1002/anie.201007987

45. Sartorel, A.; Bonchio, M.; Campagna, S.; Scandola, F. Chem. Soc. Rev. 2013, 42, 2262-2280. doi:10.1039/C2CS35287G

46. La Ganga, G.; Puntoriero, F.; Campagna, S.; Bazzan, I.; Berardi, S.; Bonchio, M.; Sartorel, A.; Natali, M.; Scandola, F. Faraday Discuss. 2012, 155, 177-190. doi:10.1039/C1FD00093D

47. Polarz, S.; Orlov, A. V.; van den Berg, M. W. E.; Driess, M. Angew. Chem., Int. Ed. 2005, 44, 7892-7896. doi:10.1002/anie.200501212

48. Berardi, S.; La Ganga, G.; Natali, M.; Bazzan, I.; Puntoriero, F.; Sartorel, A.; Scandola, F.; Campagna, S.; Bonchio, M. J. Am. Chem. Soc. 2012, 134, 11104-11107. doi:10.1021/ja303951z 49. Evangelisti, F.; Güttinger, R.; Moré, R.; Luber, S.; Patzke, G. R. J. Am. Chem. Soc. 2013, 135, 18734-18737. doi:10.1021/ja4098302

50. Yin, Q.; Tan, J. M.; Besson, C.; Geletii, Y. V.; Musaev, D. G.; Kuznetsov, A. E.; Luo, Z.; Hardcastle, K. I.; Hill, C. L. Science 2010, 328, 342-345. doi:10.1126/science. 1185372

51. Wasylenko, D. J.; Ganesamoorthy, C.; Borau-Garcia, J.; Berlinguette, C. P. Chem. Commun. 2011, 47, 4249-4251. doi:10.1039/c0cc05522k

52. Dogutan, D. K.; McGuire, R., Jr.; Nocera, D. G. J. Am. Chem. Soc. 2011, 133, 9178-9180. doi:10.1021/ja202138m

53. Das, B. K.; Chakrabarty, R. J. Chem. Sci. 2011, 123, 163-173. doi:10.1007/s12039-011-0111-6

54. Chakrabarty, R.; Bora, S. J.; Das, B. K. Inorg. Chem. 2007, 46, 9450-9462. doi:10.1021/ic7011759

55. Chakrabarty, R.; Sarmah, P.; Saha, B.; Chakravorty, S.; Das, B. K. Inorg. Chem. 2009, 48, 6371-6379. doi:10.1021/ic802115n 
56. Wang, X.; Maeda, K.; Thomas, A.; Takanabe, K.; Xin, G.;

Carlsson, J. M.; Domen, K.; Antonietti, M. Nat. Mater. 2009, 8, 76-80.

doi:10.1038/nmat2317

57. Wang, X.; Chen, X.; Thomas, A.; Fu, X.; Antonietti, M. Adv. Mater. 2009, 21, 1609-1612. doi:10.1002/adma.200802627

58. Lin, Z.; Wang, X. Angew. Chem., Int. Ed. 2013, 52, 1735-1738. doi:10.1002/anie.201209017

59. Zhang, J.; Zhang, M.; Sun, R.-Q.; Wang, X. Angew. Chem., Int. Ed. 2012, 51, 10145-10149. doi:10.1002/anie.201205333

60. Cui, Y.; Ding, Z.; Fu, X.; Wang, X. Angew. Chem., Int. Ed. 2012, 51, 11814-11818. doi:10.1002/anie.201206534

61. Lin, J.; Ding, Z.; Hou, Y.; Wang, X. Sci. Rep. 2013, 3, No. 1056. doi:10.1038/srep01056

62. Wang, S.; Yao, W.; Lin, J.; Ding, Z.; Wang, X. Angew. Chem., Int. Ed. 2014, 53, 1034-1038. doi:10.1002/anie.201309426

63. Wang, S.; Ding, Z.; Wang, X. Chem. Commun. 2015, 51, 1517-1519. doi:10.1039/C4CC07225A

64. Kuriki, R.; Matsunaga, H.; Nakashima, T.; Wada, K.; Yamakata, A.; Ishitani, O.; Maeda, K. J. Am. Chem. Soc. 2016, 138, 5159-5170. doi:10.1021/jacs.6b01997

65. Kuriki, R.; Yamamoto, M.; Higuchi, K.; Yamamoto, Y.; Akatsuka, M.; Lu, D.; Yagi, S.; Yoshida, T.; Ishitani, O.; Maeda, K. Angew. Chem., Int. Ed. 2017, 56, 4867-4871. doi:10.1002/anie.201701627

66. Kuriki, R.; Sekizawa, K.; Ishitani, O.; Maeda, K. Angew. Chem., Int. Ed. 2015, 54, 2406-2409. doi:10.1002/anie.201411170

67. Wang, S.; Hou, Y.; Wang, X. ACS Appl. Mater. Interfaces 2015, 7, 4327-4335. doi:10.1021/am508766s

68. Zhang, M.; Wang, X. Energy Environ. Sci. 2014, 7, 1902-1906. doi:10.1039/c3ee44189j

69. Zhang, G.; Zang, S.; Lin, L.; Lan, Z.-A.; Li, G.; Wang, X. ACS Appl. Mater. Interfaces 2016, 8, 2287-2296. doi:10.1021/acsami.5b11167

70. Lin, J.; Pan, Z.; Wang, X. ACS Sustainable Chem. Eng. 2014, 2, 353-358. doi:10.1021/sc4004295

\section{License and Terms}

This is an Open Access article under the terms of the Creative Commons Attribution License (http://creativecommons.org/licenses/by/4.0). Please note that the reuse, redistribution and reproduction in particular requires that the authors and source are credited.

The license is subject to the Beilstein Journal of Organic Chemistry terms and conditions:

(https://www.beilstein-journals.org/bjoc)

The definitive version of this article is the electronic one which can be found at: $\underline{\text { doi: } 10.3762 / \text { bjoc. } 14.208}$ 